\title{
Plasmid Borne Resistance in Klebsiella Isolates from Kenyatta National Hospital, Nairobi, Kenya.
}

\section{J.M. BURURIA*¹, P.N. KINYANJUI ${ }^{2}$, P.G. WAIYAKI ${ }^{3}$, S.M. KARIUKI ${ }^{3}$ AND P.N. KARIMI ${ }^{1}$}

${ }^{1}$ Department of Pharmaceutics \& Pharmacy Practice, University of Nairobi, P.O. Box 19676-00202, Nairobi, Kenya.

${ }^{2}$ Department of Biochemistry, University of Nairobi, P.O. Box 30197-00100, Nairobi, Kenya.

${ }^{3}$ Centre for Microbiology Research, Kenya Medical Research Institute, P.O. Box 19463-00202, Nairobi, Kenya.

\begin{abstract}
Eighty six Klebsiella isolates from Kenyatta National Hospital and the Centre for Microbiology, Kenya Medical Research Institute, Nairobi were screened for resistance to commonly prescribed antimicrobial agents and for their plasmid content. Plasmids were transferred into Esherichia coli $\mathrm{K}-12$ and resulting transconjugants screened for resistance to the antimicrobial agents used on Klebsiella donors and for their plasmid content. Plasmids from the Klebsiella isolates were also transformed into Eschericia coli and transformants analyzed for resistance and plasmid content. Endonuclease restriction mapping was done to characterize the plasmids from Klebsiella isolates and their Eschericia coli transformants. Resistance was found to be plasmid borne and transmissible.
\end{abstract}

Key words: Plasmid, resistance, conjugation, transformation.

\section{INTRODUCTION}

Klebsiella species have been reported as a major cause of nosocomial infections at the Kenyatta National Hospital [1-3]. Some of the infections are reported to have been caused by multi-resistant strains [1]. Bacteria that possess resistance-encoding genes can transmit them to other bacteria through the processes of conjugation, transformation, transduction or cell-cell fusion [4].

Conjugation involves cell-to-cell contact and active passage of DNA directly from one bacterial cell to another. It is far more significant in the horizontal transfer of genes in bacteria than transformation or transduction [4]. Conjugation is mediated by plasmid borne genes. The plasmid borne genes are not essential for the survival of the bacterium in its natural environment but encode a multiplicity of accessory traits that may provide their host with selective advantage under unfavourable conditions [5-6]. Accessory traits encoded by plasmids include resistance to antibiotics and other toxic agents such as heavy metals, organic compounds and ultraviolet radiation.
Resistance is encoded by plasmids referred to as R-factors. These are capable of effecting transfer of resistance determinants between strains, species and genera of bacteria, thus initiating an infectious spread of resistance [7].

This study was based on the assumption that the liberal use of antimicrobial agents may have led to the development of multiple drug resistant Klebsiella species in Kenya. It had also been assumed that Klebsiella species may transfer resistance determinants to other bacteria including pathogens sharing the same environment. There was a compelling need therefore to study the genetic basis of resistance in Klebsiella species at the Kenyatta National Hospital with a view to helping in the surveillance against establishment of hospital and community acquired resistant bacterial infections.

\section{EXPERIMENTAL}

\section{Bacterial strains}

Escherichia coli SURE strain (Epicurian coli SURE from Stratagene Cloning Systems La

\footnotetext{
*Author to whom correspondence may be addressed.
} 
Jolla, CA., USA) was obtained from the International Livestock Research Institute, Kabete, Kenya. Escherichia coli strains K$12 \mathrm{~F}^{-}, 39 \mathrm{R} 861$ and V517 were donated from the Kenya Medical Research Institute/Wellcome Trust Research Laboratory, Nairobi. Escherichia coli ATCC 25922 was obtained from the National Public Health Laboratories, Nairobi. Klebsiella species were isolated at the Microbiology Laboratories of the University of Nairobi at the Kenyatta National Hospital and also from the Centre for Microbiology Research of the Kenya Medical Research Institute.

\section{Isolation of Plasmid DNA}

A bacterial cell suspension was prepared by touching three to five isolated colonies of Klebsiella isolates using a sterile wire loop. The material was inoculated into $5 \mathrm{ml}$ of Brain Heart Infusion broth and incubated on a roller drum at $37{ }^{\circ} \mathrm{C}$ for $18 \mathrm{~h}$. A cell pellet was prepared by transferring $1.5 \mathrm{ml}$ of culture into a $2 \mathrm{ml}$ Eppendorf tube and centrifuging at 14,000 $\mathrm{rpm}$ for $90 \mathrm{~s}$ at $4{ }^{\circ} \mathrm{C}$ in a high-speed refrigerated microcentrifuge. DNA was isolated according to the procedure described by Sambrook et al. [8].

The plasmid DNA was separated by agarose gel electrophoresis carried out at $100 \mathrm{~V}$ for $2 \mathrm{~h}$. Each gel run included a molecular weight of marker consisting of DNA from the Escherichia coli strain V517 which carries plasmids of 35.8, 4.4, 3.7, 3.4, 2.6, 2.0, 1.8, and 1.4 mega daltons. Separated DNA was visualised by placing the gel on an ultraviolet trans-illuminator and photographed using a Polaroid MP-4 Land Camera and Polaroid type 55 positive/negative instant sheet film.

\section{Transformation of competent cells by plasmid DNA}

One hundred microlitres of competent cells of Escherichia coli SURE (Stop Unwanted Rearrangement Events) strain were transformed using $10 \mu \mathrm{l}$ of a DNA solution containing about $50 \mathrm{ng}$ of DNA. Two microlitres of plasmid pBR322 DNA were added to $100 \mu 1$ of competent cells and run alongside the test DNA to act as the positive control for transformation efficiency. Transformation was carried out according to the procedure described by Sambrook et al. [8]. Two hundred microlitres of the transformation mixture was inoculated onto Luria Bertani (LB) agar plates containing the antibiotic to which transfer of resistance was suspected. The mixture was spread on the agar surface using a sterile glass spreader and incubated at $37{ }^{\circ} \mathrm{C}$ overnight.

The transformation mixture containing plasmid pBR322 was plated out onto agar plates containing ampicillin only since the Escherichia coli SURE strain is inherently resistant to tetracycline, the other resistance marker on plasmid pBR322.

\section{Conjugation}

Escherichia coli $\mathrm{K}^{2} \mathrm{~F}^{-}$(nalidixic acid resistant) was used as the recipient of DNA donated by the various strains of Klebsiella. Typical colonies of both donor and recipient were inoculated into $3 \mathrm{ml}$ of LB broth and incubated at $37{ }^{\circ} \mathrm{C}$ overnight. The overnight culture was diluted to a cell density of about $6 \times 10^{8}$ cells $/ \mathrm{ml}$ using a No. 2 McFarland turbidity standard.

One $\mathrm{ml}$ of each adjusted inoculum of donor and recipient cells were mixed in $4 \mathrm{ml} \mathrm{LB}$ broth and incubated at $37{ }^{\circ} \mathrm{C}$ overnight. The overnight culture was then diluted 1:10 with a $0.9 \%$ sodium chloride solution. The diluted culture $(100 \mu \mathrm{l})$ was transferred to the surface of MacConkey agar containing either nalidixic acid alone $(20 \mu \mathrm{g} / \mathrm{ml})$ or nalidixic acid and another antibiotic.

The inoculum was spread over the surface with a sterile glass plate spreader. The plates were left to dry on the bench top and incubated at 37 ${ }^{\circ} \mathrm{C}$ for $16 \mathrm{~h}$ and examined for transconjugants. LB agar was used to test trimethoprim in order to avoid the breakthrough growth that occurs when trimethoprim is tested on MacConkey 
agar [9]. Plasmid DNA was extracted from the transconjugants for comparison with that from donor Klebsiella isolates.

\section{Restriction endonuclease digestion}

Two microlitres of a solution containing about $100 \mathrm{ng}$ of DNA were placed into an Eppendorf tube and mixed with $16 \mu \mathrm{l}$ of sterile water. Two microlitres of a $\times 10$ restriction enzyme buffer was added to the tube and mixed by tapping the tube.Two units of Hind III were added to the tube and mixed by tapping the tube. The mixture was then incubated for 10 minutes in a water bath at $37{ }^{\circ} \mathrm{C}$. The reaction was stopped by adding $0.4 \mathrm{ml}$ of a $0.5 \mathrm{M}$ solution of EDTA. Six microlitres of gel loading buffer was then added to the digest before being loaded into agarose gel for electrophoresis.

\section{RESULTS AND DISCUSSION}

The isolates exhibited fourteen different plasmid profiles as shown in Table 1. These profiles did not correspond to resistance patterns (Figure 1). This suggests that the strains did not have any clonal relation and did not represent an epidemic strain. The profiles may be a reflection of the diversity of sources of the isolates. Similar findings have previously been reported with strains of identical resistance patterns showing markedly different plasmid profiles [10-11]. Conjugation studies showed the presence of transmissible plasmids that conferred resistance to Escherichia coli $\mathrm{K}-12$. Transfer of resistance to amoxicillin by conjugation shows that besides chromosomal carriage of resistance determinants inherent in Klebsiella species there are additional determinants on plasmids.

In figure 1 lanes A, B, C, D, E, F, G, H, J and $\mathrm{K}$ contain DNA from multi-resistant isolate numbers E68, 4988, 4998, 5011, 5016, E4510, 5052, 5232, 5054, and 5264. Lane I contains plasmid DNA from isolate number M434 which was susceptible to all antimicrobial agents tested except amoxicillin and sulphamethoxazole. Lane L contains plasmid molecular size marker DNA from E. coli strain V517. Plasmid size is shown in mega Daltons (MDa). Chr indicates the chromosomal DNA band. The plasmids were classified as either heavy or light depending on their mobility relative to the chromosomal DNA band. Those with lower mobility than chromosomal DNA were regarded heavy while those with higher mobility were regarded as light. Lanes A, G and I show isolates with mixed plasmid patterns while lanes B, C, D and K show heavy plasmids. Lane $\mathrm{E}$ shows an isolate with light plasmids. In lanes $\mathrm{F}, \mathrm{H}$, and $\mathrm{J}$ only the chromosomal band is visible.

This study also revealed the possibility of linked resistance to several antibiotics. In one instance resistance to amoxicillin was transferred together with that to tetracycline, sulphamethoxazole and gentamicin (Table 2). It has been reported that for antimicrobial agents whose resistances are linked, the absence of one agent does not reduce the prevalence of resistance to it [12]. Therefore,

Table 1: Distribution of plasmids among Klebsiella isolates

\begin{tabular}{lllc}
\hline \multirow{2}{*}{ Pattern } & \multicolumn{2}{c}{ Plasmid type } & $\begin{array}{c}\text { Number } \\
\text { isolates }\end{array}$ \\
\cline { 2 - 4 } Heavy & Light & \\
\hline 1 & - & 1 & 5 \\
2 & - & 2 & 3 \\
3 & - & 3 & 3 \\
4 & - & 4 & 2 \\
5 & - & 5 & 3 \\
6 & 1 & - & 18 \\
7 & 2 & - & 3 \\
8 & 1 & 1 & 6 \\
9 & 1 & 2 & 14 \\
10 & 1 & 3 & 6 \\
11 & 1 & 4 & 4 \\
12 & 1 & 5 & 1 \\
13 & 2 & 1 & 2 \\
14 & 2 & 3 & 1 \\
\hline
\end{tabular}




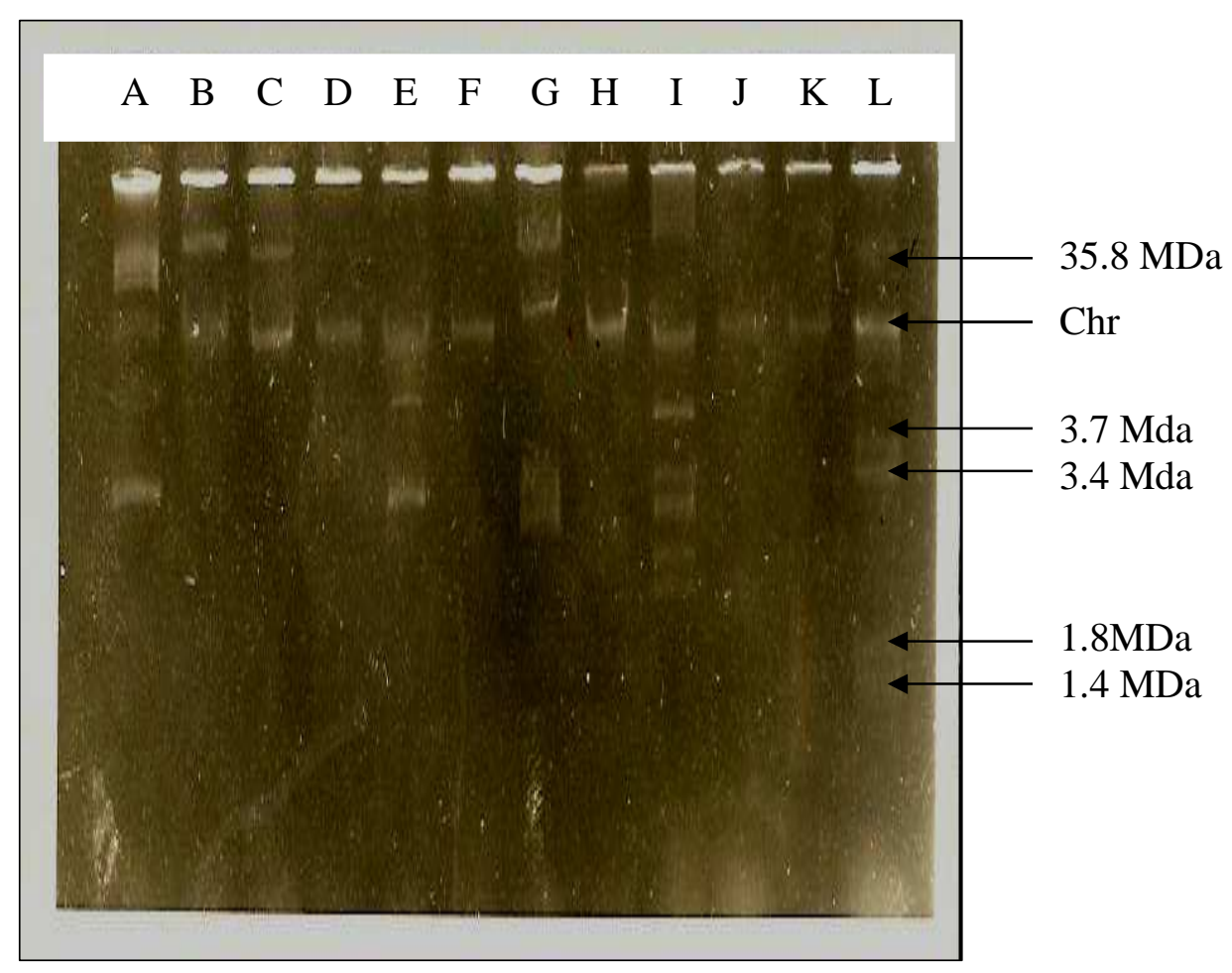

Figure 1: Gel showing plasmids from various Klebsiella isolates.

the major pressure for selection of gentamicin resistant strains may have been the use of amoxicillin and co-trimoxazole rather than gentamicin itself.

Tetracycline resistance was also co-transferred with that to other drugs like chloramphenicol and trimethoprim in the conjugation studies. Resistance to trimethoprim was always associated with that to sulphamethoxazole. This is comparable to the findings in other studies [13].

In some cases, resistance was transferred without evidence of responsible plasmids. Resistance determinants in such cases may be carried on low copy plasmids which may be difficult to visualize in gels and may thus not be accounted for. Large plasmids may also be involved. These would get sheared during isolation and then get co-precipitated with chromosomal DNA and also co-migrate with it [14].
Transformation resulted in the transfer of plasmids as shown by inclusion of the DNA of plasmid pBR322 (4.36 kilobase pairs in size) in the agarose gels (Figure 2). Transfer of plasmids was also accompanied by resistance transfer. This proves that the isolates carried plasmid borne resistance determinants.

In figure 2, lanes A and $\mathrm{H}$ contain the Hind III digested lamda DNA molecular weight markers. Lane B carries undigested lamda DNA while Lane $\mathrm{C}$ carries the Hind III digested pBR322. Lane D shows the pattern of Klebsiella isolate 4840, while lane E shows the pattern of the Escherichia coli SURE strain transformant of isolate 4840. Lanes F and G are empty. Fragment lengths are expressed in kilobase pairs $(\mathrm{kb})$.

Transformation resulted in the transfer of resistance to only four drugs including amoxicillin, streptomycin, sulphamethoxazole 
Table 2: Resistance transfer from Klebsiella isolates to Escherichia coli K-12 by conjugation

\begin{tabular}{lllllll}
\hline Isolate & & \multicolumn{5}{c}{ Transfer of resistance to } \\
number & AMOX & CHLO & GENT & TRIM & SULP & TETR \\
\hline E494 & & & $\sqrt{ }$ & $\sqrt{ }$ & \\
4553 & & & $\sqrt{ }$ & $\sqrt{ }$ & $\sqrt{ }$ \\
4426 & & & $\sqrt{ }$ & $\sqrt{ }$ & \\
E568 & $\sqrt{ }$ & & $\sqrt{ }$ & $\sqrt{ }$ & $\sqrt{ }$ \\
1962 & & $\sqrt{ }$ & & & $\sqrt{ }$ & $\sqrt{ }$ \\
5493 & & $\sqrt{ }$ & & $\sqrt{ }$ & $\sqrt{ }$ & $\sqrt{ }$ \\
5489 & & & & $\sqrt{ }$ & $\sqrt{ }$ & $\sqrt{ }$ \\
4828 & & & & & $\sqrt{ }$ & $\sqrt{ }$ \\
5492 & & & & $\sqrt{ }$ & $\sqrt{ }$ & $\sqrt{ }$ \\
8943 & & & & & $\sqrt{ }$ & $\sqrt{ }$ \\
8814 & & & & $\sqrt{ }$ & $\sqrt{ }$ & $\sqrt{ }$ \\
D1216 & $\sqrt{ }$ & & & & & \\
\hline
\end{tabular}

AMOX=Amoxicillin, $\mathrm{CHLO}=$ Chloramphenicol, GENT=Gentamicin , SULP=Sulphamethoxazole, TETR $=$ Tetracycline, TRIM= Trimethoprim, $\sqrt{ }=$ Transfer

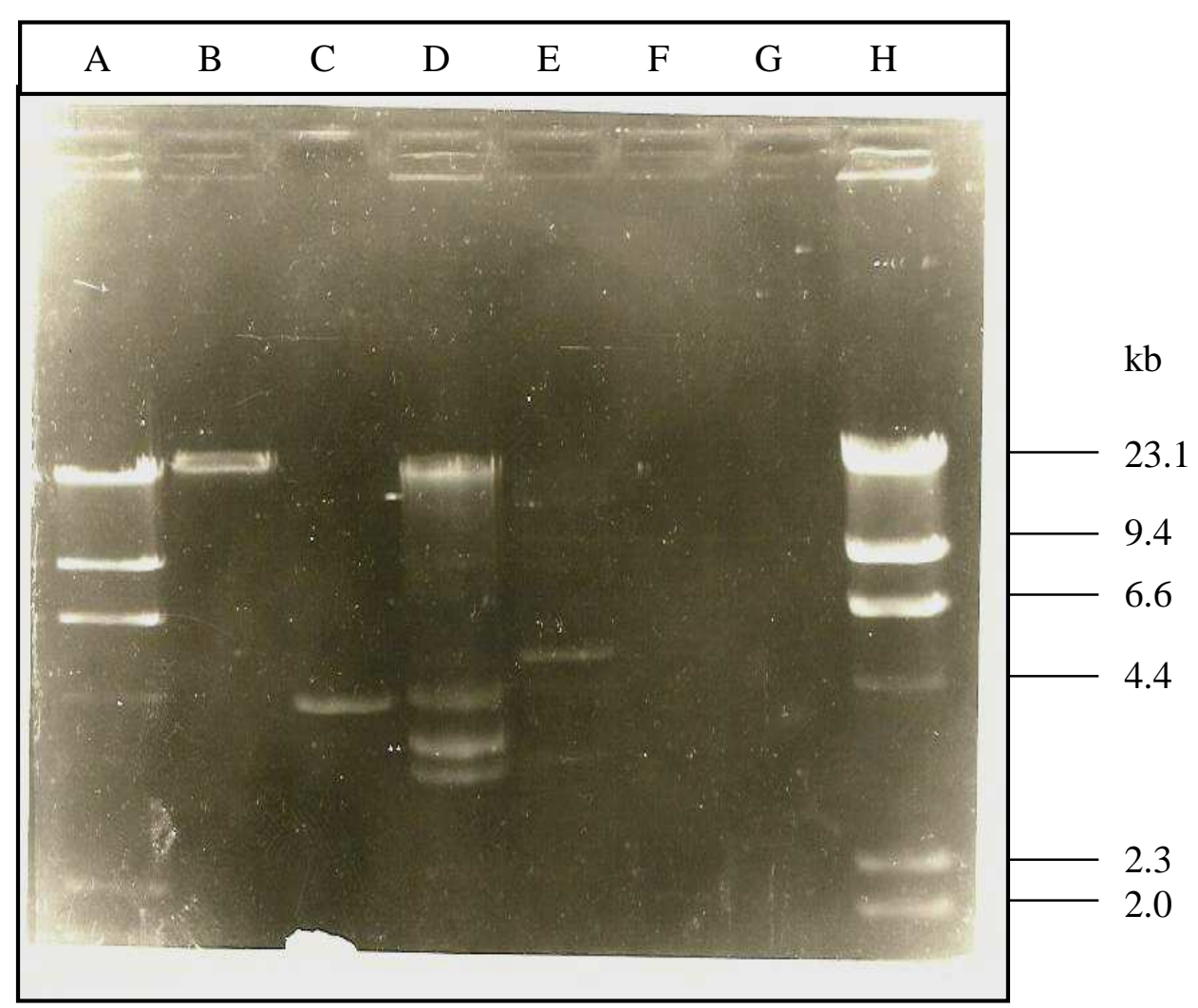

Figure 2: Hind III restriction fragments of plasmid DNA from a Klebsiella donor and its Escherichia coli SURE strain recipient. 
and trimethoprim. Resistance determinants to other drugs may have been transferred but could not be shown. Failure of an expected phenotype following transformation may arise due to failure of gene expression in new hosts [15]. Additionally, it has been reported that expression of plasmid encoded genes is affected by multiple factors including genetic organization, promoter modifications, genetic background, and to some extent plasmid copy number [16]. This shows that dependence on

\section{REFERENCES}

[1] J.N. Muthotho, P.G. Waiyaki, M. Moninda and J. Karuri, Programme Abstracts, International Congress for Infectious Diseases, Montreal, Canada. 1990, Abstract No. 569.

[2] S. Kariuki, J.E. Corkill, G. Revathi, R. Musoke and C.A. Hart, Antimicrob. Agents Chemother. 45 (2001) 21412143.

[3] D. Senerwa and Ø. Olsvik in Ø. Olsvik and G. Bulkhorm, (eds.), Proceedings of an International Symposium on Applications of Molecular Biology in Diagnosis of Infectious Diseases, Oslo, Norway. 1990, p 21-25.

[4] P.M. Bennet and T.G.B. Howe in M.T. Parker, L.H. Collier, A.H. Linton and H.M. Dick, (eds.), Topley and Wilsons Principles of Bacteriology, Virology and Immunity Volume 1. Edward Arnold, London. 1990, pp 153-210.

[5] R.P. Novick, Sci. Amer. 243 (1980) 76-90.

[6] K.N. Timmis, M.I. Gonzalez-Carrero, T. Sekizuki and F. Rojo, J. Antimicrob. Chemother. 18 (1986) 1-12.

[7] T.J. Franklin in H.B. Hugo and A.D. Russel, (eds.), Pharmaceutical Microbiology. Blackwell Scientific publications, Oxford. 1992, pp 208230. phenotypic methods for bacterial typing is clearly inadequate, since a phenotype is dependent on gene expression and on environmental factors as well.

In conclusion, it is recommended that for effective surveillance against the spread of multi-resistant isolates such as those encountered in this study, there should be an integration of both phenotypic and genotypic methods of assessing resistance.

[8] J. Sambrook, E.F. Fritsch and T. Maniatis, Molecular Cloning: A Laboratory Manual. 2nd Ed, Coldspring Harbor Laboratory, Cold Harbor, New York. 1989.

[9] C.L. Wells, R.P. Pozorski, P.K. Peterson, N.K. Ramsay, R.L. Simmons and F.S.J. Rhame, Infect. Dis. 15 (1984) 699-706.

[10] I.A. Adeleye and A.I.E. Adetosoye, E. Afr. Med J. 70 (1993) 259-262.

[11] M. Sherley, D.M. Gordon and P.J. Collignon, Microbiol. $150 \quad$ (2004) 1539-1546.

[12] V.I. Enne, D.M. Livermore, P. Stephens and L.M. Hall, Lancet 357 (2001) 1890.

[13] E. Heikilla, L. Sundstrom and P. Huovinen, Antimicrob. Agents Chemother. 34 (1990) 2013-2015.

[14] A.J. Hartstein, V.H. Morthland, J.W. Rourke, R. Sykes and A.L. Rashad, Diagn. Microbiol. Infect. Dis. 16 (1993) 35-41.

[15] R.W. Hedges, A.E. Jacob and I.P. Crawford, Nature (London) 267 (1977) 283-284.

[16] M.D. Reisbig, A. Hossain, and N.D. Hanson, J. Antimicrob. Chemother. 51 (2003) 1141-1151. 